\title{
Adipose Tissue Expression of $11 \beta$-Hydroxysteroid Dehydrogenase Type 1 in Cushing's Syndrome and in Obesity
}

\begin{abstract}
Glucocorticoids have a major role in determining adipose tissue metabolism and distribution. 11 $\beta$-hydroxysteroid dehydrogenase type $1(11 \beta \mathrm{HSD} 1)$ is a NADPHdependent enzyme highly expressed in the liver and adipose tissue. In most intact cells and tissues it functions as a reductase (to convert inactive cortisone to active cortisol). It has been hypothesized that tissue-specific deregulation of cortisol metabolism may be involved in the complex pathophysiology of the metabolic syndrome (MS) and obesity. Transgenic mice overexpressing $11 \beta$ HSD1 in adipose tissue develop obesity with all features of the MS, whereas $11 \beta$ HSD1-knockout mice are protected from both. The bulk of evidences points to an overexpression and increased activity of $11 \beta \mathrm{HSD} 1$ also in human adipose tissue. However, $11 \beta$ HSD1 seems to adjust local cortisol concentrations independently of its plasma levels. In Cushing's syndrome, 11ßHSD1 is downregulated and may not be responsible for the abdominal fat depots; it also undergoes downregulation in response to weight loss in human obesity. The nonselective $11 \beta$ HSD1 inhibitor carbenoxolone improves insulin sensitivity in humans, and selective inhibitors enhance insulin action in diabetic mice liver, thereby lowering blood glucose. Thus, $11 \beta \mathrm{HSD} 1$ is now emerging as a modulator of energy partitioning and a promising pharmacological target to treat the MS and diabetes. (Arq Bras Endocrinol Metab 2007;51/8:1397-1403)
\end{abstract}

Keywords: $11 \beta$-hydroxysteroid dehydrogenase type 1; Adipose tissue; Cortisol; Cortisone; Metabolic syndrome; Obesity; Cushing's syndrome

\section{RESUMO}

\begin{abstract}
Expressão da 11ß-Hidroxisteróide Desidrogenase Tipo 1 no Tecido Adiposo na Síndrome de Cushing e na Obesidade.

Os glicocorticóides (GC) têm papel importante na determinação do metabolismo e da distribuição do tecido adiposo. A 11ß-hidroxisteróide desidrogenase tipo 1 (11ßHSD1) é uma enzima dependente de NADPH, altamente expressa nos tecidos hepático e adiposo. Em muitas células e tecidos intactos, ela funciona como redutase (convertendo cortisona em cortisol). Postula-se que uma desregulação tecido-específica do cortisol estaria envolvida na complexa fisiopatologia da síndrome metabólica (SM) e obesidade. Ratos que superexpressam $11 \beta \mathrm{HSD} 1$ no tecido adiposo desenvolvem obesidade e todas as características da SM, enquanto ratos knockout para $11 \beta \mathrm{HSD} 1$ são protegidos. Evidências apontam para uma super-expressão e aumento da atividade $11 \beta$ HSD1 também no tecido adiposo humano. Entretanto, a $11 \beta \mathrm{HSD} 1$ parece ajustar a concentração local de cortisol independente da sua concentração sérica. Na síndrome de Cushing, a expressão da 11ßHSD1 é regulada para baixo, não devendo ser a causa dos depósitos de gordura visceral; em obesos, há também regulação para baixo em resposta à perda de peso. A carbenoxolona, um inibidor não seletivo da 11ßHSD1, melhora a sensibilidade insulínica em humanos e inibidores seletivos aumentam a sensibilidade insulínica hepática e melhoram o controle glicêmico em ratos diabéticos. Assim, a 11ßHSD1 está emergindo como um modulador da compartimentalização de energia e um alvo farmacológico promissor para o tratamento da SM e do diabetes. (Arq Bras Endocrinol Metab 2007;51/8:1397-1403)
\end{abstract}

Descritores: 11 $\beta$-hidroxisteróide desidrogenase tipo 1; Tecido adiposo; Cortisol; Cortisona; Síndrome metabólica; Obesidade; Síndrome de Cushing atualização

\author{
DANIELA ESPÍNDOLA-ANTUNES \\ Claudio E. Kater
}

Division of Endocrinology and Metabolism, Department of Medicine, Federal University of São Paulo (UNIFESP/EPM),

São Paulo, SP.

Recebido em 30/07/07

Aceito em 10/08/07 


\section{THE INTRIGUING HISTORY OF

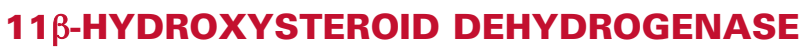

Hirty years ago (1977), Stanley Ulick described a syndrome characterized by hypertension, hypokalemia and reduced plasma renin activity (1), typical manifestations of mineralocorticoid excess. Interestingly, blood and urine levels of all known mineralocorticoids were normal. Accordingly, this condition was termed "syndrome of apparent mineralocorticoid excess" (AME). The defect did not appear to be in the renin-angiotensin-aldosterone system, but instead in the peripheral metabolism of cortisol (F), as shown later (2).

In the late 1980s, $11 \beta$-hydroxysteroid dehydrogenase (11 $\beta$ HSD) was described as an enzyme responsible for inactivation of physiologically active $\mathrm{F}$ to inert cortisone (E). This process occurs mainly at the kidney level, conferring protection to the unselective mineralocorticoid receptor (MCR). Congenital deficiency of $11 \beta \mathrm{HSD}$ is responsible for the AME syndrome that could be reproduced by exaggerated licorice ingestion (glycirrhyzinic acid, the active principle of licorice, inhibits $11 \beta \mathrm{HSD}$ ). In both conditions, $\mathrm{F}$ acts as a potent mineralocorticoid in the kidney tubule, activating the MCR similarly to aldosterone, but at a higher concentration.

At that time, however, 11 $\beta$ HSD had an unexplained two-way function: to convert $\mathrm{F}$ into $\mathrm{E}$ and, conversely, E into F. Early on, two isoforms of $11 \beta H S D$ were cloned and characterized: $11 \beta H S D$ type 1 (11 $\beta$ HSDl) and $11 \beta \mathrm{HSD}$ type $2(11 \beta \mathrm{HSD} 2)$ $(3,4)$. The former is a low-affinity $\operatorname{NADP}(\mathrm{H})$-dependent dehydrogenase/oxoreductase (cortisol to cortisone and vice-versa, respectively), which was originally identified in the liver, but that is also highly expressed in adipose, gonadal, and central nervous system tissues. By contrast, $11 \beta \mathrm{HSD} 2$ is a high-affinity NADdependent dehydrogenase, whose sole action is to protect the non-selective MCR in the kidney, colon, and salivary glands from cortisol occupancy. 11 $\beta$ HSD 1 was first regarded by Lakshmi and Monder (3) as a weaker version of $11 \beta \mathrm{HSD} 2$, because it showed dehydrogenase activity in tissues homogenates and microsomes, however evidence has now accumulated to show that in most intact cells and organs 11ßHSDl catalyses the reverse reaction (figure 1) (5).

It has been hypothesized that tissue-specific dysregulation of cortisol metabolism may be involved in the complex pathophysiology of the metabolic syndrome (MS) and simple obesity. 11ßHSDl is expressed in both adipocyte and preadipocyte (6); based
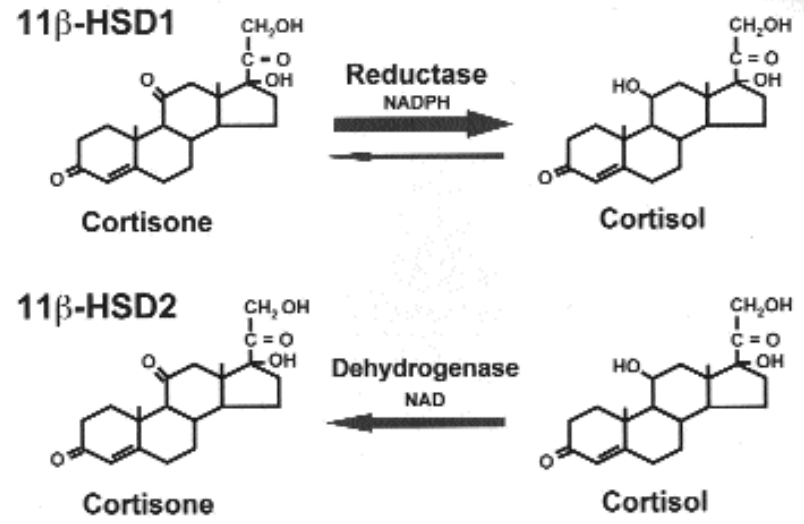

Figure 1. The $11 \beta \mathrm{HSD}$ isoenzymes: (1) $11 \beta \mathrm{HSD} 1$ is a NADPHdependent reductase (that converts inactive cortisone to active cortisol) and a dehydrogenase (that converts cortisol to cortisone), expressed in the liver, adipose, gonadal and central nervous system tissues. 11 $\beta$ HSD1 functions mostly as a reductase in intact cells and organs. (2) $11 \beta \mathrm{HSD} 2$ is a NADdependent dehydrogenase enzyme that is highly expressed in the kidney and colon.

on the evidence that glucocorticoids induce adipocyte differentiation in vitro (7), adipose autocrine generation of $\mathrm{F}$ from $\mathrm{E}$ may be implicated in the pathogenesis of central obesity and its associated metabolic complications. In support to this hypothesis, transgenic mice overexpressing $11 \beta \mathrm{HSDl}$ in adipose tissue develop obesity with all the features of the MS (8); conversely, 11 $\beta \mathrm{HSDl}$-knockout mice are protected from obesity and MS (9). Aside some controversies, the bulk of evidences show that $11 \beta \mathrm{HSDl}$ mRNA and activity are upregulated in human obesity.

\section{CUSHING'S SYNDROME AND METABOLIC SYNDROME: HIGH CIRCULATING LEVELS VERSUS HIGH TISSUE CONCENTRATIONS OF GLUCOCORTICOIDS}

\section{Cushing's syndrome: Effects of chronic exposure to high concentrations of circulating cortisol}

In 1932, Harvey Cushing reported on eight patients with adrenal hyperplasia associated with pituitary basophilic adenomas (10), defining a new clinical entity that now bears his name: "Cushing's disease". His meticulous description gives information about the deleterious effects of cortisol excess. Cushing's syndrome (CS) causes hypertension in more than $90 \%$ of the cases, central obesity in more than $80 \%$, osteoporosis in $50 \%$ (11), in addition to other typical signs and symptoms (12).

Glucocorticoids have a major role in determining adipose tissue metabolism and distribution. Sub- 
jects with endogenous or exogenous Cushing's syndrome develop a central obesity pattern that is reversible upon treatment or glucocorticoid withdrawal. Cortisol augments directly or indirectly the total mass of adipose tissue and redistributes it from peripheral to central depots (13). Glucocorticoids also regulate multiple processes in the adipose tissue. They influence fat cell size, so that enlarged abdominal fat cells are seen in CS (14); promote differentiation of human preadipocytes into mature adipocytes, increasing fat cell number (7); and activate lipolyses, releasing free fatty acids into circulation. Chronically, however, as seen in CS, lipoprotein lipase activity is elevated 2-3 fold with a low lipolytic capacity (14).

Moreover, part of the glucocorticoid actions is regulated at a pre-receptor level by $11 \beta-H S D l$. This enzyme is co-localized with the glucocorticoid receptor in several cells, including adipose tissue and liver, where it is ideally positioned to amplify glucocorticoid action. Bujalska et al. (6) cultured omental adipose stromal cells with cortisol and showed an increased activity of $11 \beta-H S D 1$. This observation led to the speculation that $11 \beta-\mathrm{HSDl}$ is upregulated in the visceral adipose tissue of subjects with Cushing's syndrome. However, recent data evidence the opposite, as will be discussed below. 11 $\beta$-HSDl seems not to be the cause of the metabolic syndrome, but instead a modulator of energy partitioning (15).

\section{Obesity and metabolic syndrome: Increased adipose tissue concentrations of cortisol}

Since the original description of "Syndrome X" by Gerald Reaven in 1988 (16), obesity has been associated, to some extent, to abnormalities in the hypothalamus-pituitary-adrenal (HPA) axis. Similarities between Cushing's syndrome and the clinical features of the metabolic syndrome (visceral obesity, hyperglycemia, hypertension, and dyslipidemia) led to the hypothesis that obesity may be associated with glucocorticoid excess in the latter.

Correlations between abdominal fat and hyperactivity of the HPA axis have been found, although there is considerable controversy in the literature. The proposed alterations include resistance to the negative feedback (impaired suppression) exerted by low oral dexamethasone or intravenous doses of glucocorticoids (17-19); elevated diurnal ACTH levels and altered pulsatile secretory ACTH dynamics (20), hyperesponsiveness to different peptides (CRH, AVP) $(21)$, and increased cortisol production rate, as measured by stable isotope ratio $(22)$.

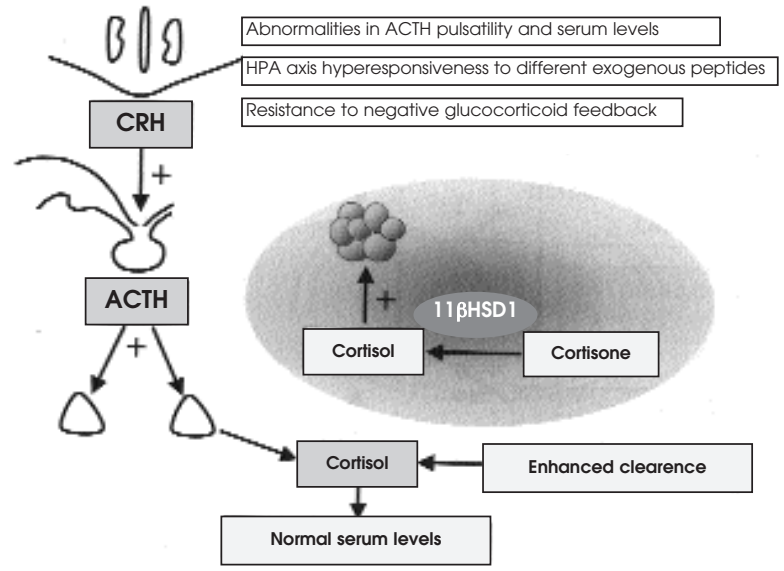

Figure 2. Abnormalities in the central regulatory control and in the peripheral metabolism of cortisol in obesity. Increased hypothalamus-pituitary-adrenal axis (HPA) drive appears to result from elevated peripheral cortisol clearance, the balance of which yields normal plasma levels. Peripherally, mRNA expression and enzymatic activity of $11 \beta \mathrm{HSD} 1$ is increased in the adipose tissue (inset).

The increased HPA axis drive and production of cortisol observed in obese subjects is counterbalanced by enhanced urinary excretion rate of free cortisol and its metabolites and also by its enhanced peripheral clearance (21-23), resulting in normal (or even low) blood levels (figure 2). This has been recently explained by observations that there is a tissue-specific deregulation of cortisol metabolism in human obesity in which $11 \beta \mathrm{HSDl}$ activity is upregulated in adipose tissue and underegulated in the liver, resulting in lower plasma cortisol levels with a compensatory rise in ACTH and cortisol production (see below).

\section{1 $\beta$-HSD1 IN OBESITY AND METABOLIC SYNDROME}

\section{In vitro studies and animal models}

Omental adipose stromal cells treated with cortisol and insulin show increased $11 \beta \mathrm{HSD} 1$ reductase activity (generation of active cortisol from inactive cortisone), suggesting that obesity may reflect a "Cushing's disease of the omentum" (6). These cells in early stage of differentiation show a switch from dehydrogenase (inactivation of cortisol into cortisone) to reductase activity, ensuring autocrine generation of cortisol, which will induce adipocyte differentiation (7). Thus, $11 \beta$ HSDl seems to play a key role in adipocyte differentiation and in regulating adipose tissue depots.

Series of studies in animal models of obesity have shown increased 11ßHSDl mRNA expression 
and activity in adipose tissue. Transgenic mice overexpressing $11 \beta H S D 1$ in adipose tissue develop obesity and other features of the metabolic syndrome, presenting with elevated intra-adipose glucocorticoid concentrations and higher glucocorticoid receptor alpha (GR $\alpha$ ) expression (24). In contrast, 11ßHSD1knockout mice are protected from obesity and its metabolic complications (9). Overexpression of $11 \beta$ HSDl in the liver does not induce obesity or hyperglycemia, although there are changes in serum lipids, insulin sensitivity and blood pressure (25). Besides, 11 $\beta$ HSDl appears to be involved in the homeostatic adaptation to macronutrient intake; it undergoes downregulation in adipose tissue of highfat feeding mice (26).

In rodents, pharmacologic inhibition of $11 \beta H S D l$ is effective in enhancing hepatic insulin sensitivity and lowering blood glucose in diabetic mice (27) and inducing weight loss in obese mice (28).

\section{Human studies}

The bulk of evidences points both to an overexpression and an increased activity of $11 \beta \mathrm{HSDl}$ in subcutaneous (SAT) and visceral adipose tissue (VAT) of obese subjects, although biopsies of the omentum were conducted in but a few studies. Several groups have shown higher $11 \beta \mathrm{HSDl}$ mRNA expression in obese compared to non-obese subjects (29-32), although not all studies agree (33). Direct in vivo measurements using microdialysis in SAT also suggest an increase in the conversion rate of cortisone to cortisol (34). Moreover, 11 $\beta$ HSDl mRNA expression positively correlates with obesity (body mass index and abdominal circumference), body composition, insulin resistance (30-32), resistins and other cytokines, as TNF $\alpha$, IL-6, and leptin (35).

The whole body $11 \beta \mathrm{HSD}$ activity reflects mainly hepatic expression. Initial studies that relied on measurements of cortisol-to-cortisone metabolites in urine $(23,36)$ should be taken with caution as indicative of 11ßHSDl activity, because several other cortisol and cortisone metabolizing enzymes are deregulated in obesity (36). Of greater importance is the finding of reduced hepatic $11 \beta \mathrm{HSD} 1$ activity measured by the conversion of orally administered cortisone to cortisol $(23,37)$. Thus, $11 \beta$ HSDl upregulation in obesity seems not to be a generalized process. In both the whole body and the splanchnic circulation there are no differences between obese and lean subjects regarding cortisol regeneration rates (as measured by $\left[{ }^{2} \mathrm{H} 4\right]$-cortisol tracer), presumably because an upregulation in adipose tissue is counterbalanced by a downregulation in the liver (15).
Polymorphisms in the $11 \beta H S D I$ gene were identified in an attempt to clarify the basis for the increased activity of adipose tissue $11 \beta \mathrm{HSDl}$ in obesity. In two populations, polymorphisms were associated with an increased risk of diabetes and hypertension, but not obesity $(38,39)$. A polymorphism was also found that predicts lower 11 1 HSDI expression and protection against diabetes (40).

\section{1 $\beta$-HSD1 IN CUSHING'S SYNDROME}

In view of this background, it has been speculated that visceral fat depot in Cushing's syndrome (CS) was due to increased $11 \beta \mathrm{HSDl}$ activity. However, there is only one published study to date on CS that shows the opposite. Mariniello et al. (41) found no differences in $11 \beta H S D l$ mRNA expression between CS patients and normal weight controls, although $11 \beta \mathrm{HSDl}$ mRNA was 13-fold higher in obese subjects. Recent observations performed by our group (42) are in agreement with Mariniello group's data (41). Our data in patients with CS also establish the absence of correlation between $11 \beta \mathrm{HSDl} \mathrm{mRNA}$ expression in VAT and salivary free cortisol (42). In CS, $11 \beta \mathrm{HSD} 1$ expression may be downregulated by chronic exposure to cortisol levels with a compensatory upregulation of GR $\alpha$ (42).

$11 \beta \mathrm{HSDl}$ is emerging as a key component in homeostatic adaptation, rather than the cause of fattyacid accumulation in adipose tissue. Recent studies suggest that the enzyme is influenced by the nutritional status (15); accordingly, its lack of increase in CS may suggest a protective mechanism against the metabolic complications. Indeed, when the opposite occurs, e.g., weight loss in simple obesity, 11ßHSDl undergoes upregulation (43), although this is not a universal finding (32). Thus, there are some evidences that $11 \beta \mathrm{HSDl}$ adjusts local cortisol concentrations independently of its circulating levels.

\section{REGULATION OF $11 \beta$-HSD1 EXPRESSION}

A number of factors are known to regulate mRNA $11 \beta H S D 1$ levels and activity. In cultured adipose cells, glucocorticoids, PPAR $\gamma$ agonists, pro-inflammatory citokynes (TNF $\alpha$, ILl), and leptin, all increase $11 \beta H S D l$ expression, whereas $\mathrm{GH}$ and thiazolidinediones inhibit it [for review see Tomlinson et al. (44)] (figure 3). However, it should be appreciated that findings in isolated cell cultures and in rodents are not always reproducible in humans. For example, Wake et al. (45) found that rosigli- 


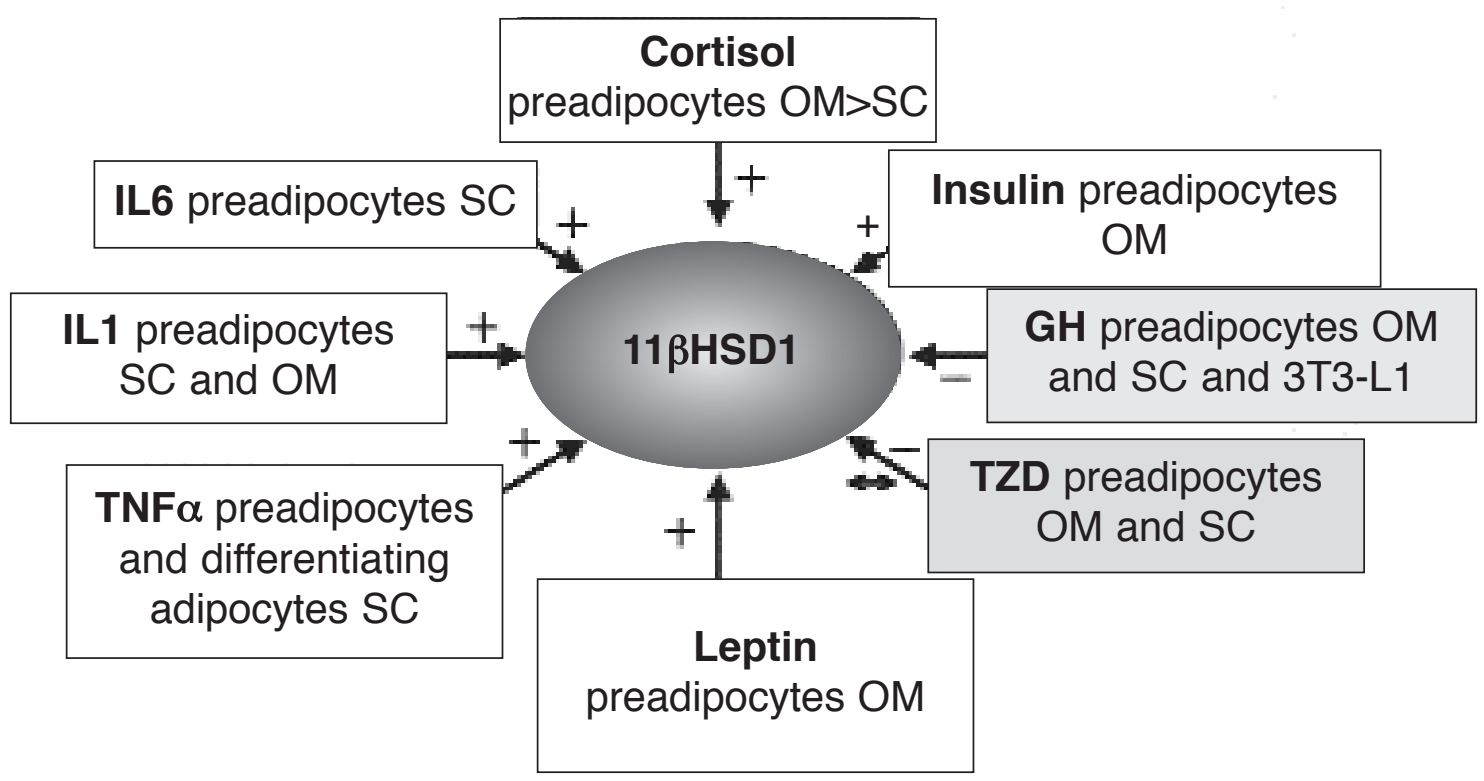

Figure 3. Some of the factors involved in the complex adipose tissue regulation of $11 \beta \mathrm{HSD} 1$ enzyme. [+], [-], [↔]: increase, inhibit, or do not change expression, respectively.

OM: omental adipose tissue, SC: subcutaneous adipose tissue, IL-6: interleukyne 6, IL-1: interleukyne 1, TNF $\alpha$ : tumor necrosis factor- $\alpha$, TZD: thiazolidinediones, GH: growth hormone.

tazone, a PPAR $\gamma$ agonist, did not change 11ßHSDl mRNA expression and activity in human SAT, at least acutely.

In addition, recent research has begun to address the question of $11 \beta \mathrm{HSDl}$ regulation in healthy subjects, and suggest that the enzyme is influenced by the nutritional status (15). A single mixed meal induces a rise in whole body rates of regeneration of cortisol by $11 \beta \mathrm{HSDl}$ (46), an effect that seems mediated by hyperinsulinemia (47).

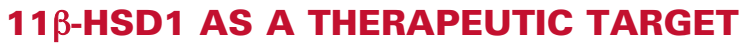 FOR THE METABOLIC SYNDROME AND DIABETES}

Inhibition of $11 \beta \mathrm{HSD} 1$ shows a considerable promise as a therapeutic target to the metabolic syndrome and type 2 diabetes. It offers a key advantage over other strategies for manipulating glucocorticoid action, in that circulating cortisol levels and the response to stress are not impaired. Ideally, it would reduce glucocorticoid action selectively within the metabolically active tissues such as adipose and liver, without blunting the negative feedback regulation at the HPA axis. $11 \beta H S D l$ is important for glucocorticoid action also in the brain, in addition to HPA axis regulation (48). To avoid hypothalamic interference by specific
$11 \beta$ HSDl inhibitors, such drugs must not cross the blood-brain barrier (49).

Pharmacologic inhibition of $11 \beta \mathrm{HSDl}$ with the anti-ulcer drug carbenoxolone improves insulin sensitivity in healthy human subjects (50) and in patients with type 2 diabetes (51). However, carbenoxolone is neither selective nor very potent and does not appear to inhibit 11ßHSD 1 in adipose tissue. Arylsulphonamidothiazoles were the first $11 \beta \mathrm{HSDl}$ selective inhibitors to be synthesized; in diabetic mice, they enhance insulin action in the liver, thereby lowering blood glucose concentrations (27).

To date approximately eighteen pharmaceutical companies and other organizations have filled patents for $11 \beta \mathrm{HSDl}$ inhibitors (15). Results of clinical studies with novel potent inhibitors are therefore eagerly awaited.

\section{CONCLUSION}

Several controversies on $11 \beta H S D 1$ expression and activity in human adipose tissue remain unsolved. However, there are accumulating evidences that intra-adipocyte generation of cortisol contributes for the development of features of the MS and type 2 diabetes. Several groups have shown upregulation of $11 \beta \mathrm{HSDl}$ in obesity and its correlation with abdominal circumference, BMI, and 
insulin resistance. In Cushing's syndrome, $11 \beta \mathrm{HSDl}$ is downregulated, suggesting that it may adjust local cortisol concentrations independently of its plasma levels. $11 \beta$ HSDl seems also to play a role in the complex pathophysiology of the MS and in energy partitioning. Future clinical studies are envisioned to prove the efficacy of selective 11 $\beta \mathrm{HSDl}$ inhibition.

\section{REFERENCES}

1. New MI, Levine LS, Biglieri EG, Pareira J, Ulick S. Evidence for an unidentified steroid in a child with apparent mineralocorticoid hypertension. J Clin Endocrinol Metab 1977;44:924-33.

2. Ulick S, Levine LS, Gunczler P, Zanconato G, Ramires LC, Raul W, et al. A syndrome of apparent mineralocorticoid excess associated with defects in the peripheral metabolism of cortisol. J Clin Endocrinol Metab 1979;49:757-64.

3. Lakshmi V, Monder C. Purification and characterization of the $11 \beta$-dehydrogenase component of the rat liver $11 \beta$-hydroxysteroid dehydrogenase complex. Endocrinology 1988; 123:2390-8.

4. Low SC, Assaad SN, Rajan V, Chapman KE, Edwards CR, Seckl JR. Regulation of $11 \beta$-hydroxysteroid dehydrogenase by sex steroids in vivo: further evidence for the existence of a second dehydrogenase in rat kidney. J Endocrinol 1993; 139:27-35.

5. Seckl JR, Walker BR. 11ß-hydroxysteroid dehydrogenase type 1 as a modulator of glucocorticoid action: from metabolism to memory. Trends Endocrinol Metab 2004;15:418-24.

6. Bujalska IJ, Kumar S, Stewart PM. Does central obesity reflect "Cushing's disease of the omentum"? Lancet 1997;349: 1210-3.

7. Bujalska IJ, Kumar S, Hewison M, Stewart PM. A switch in the dehydrogenase to reductase activity of $11 \beta$-hydroxysteroid dehydrogenase type 1 upon differentiation of human omental adipose stromal cells. J Clin Endocrinol Metab 2002;87:1205-10.

8. Masuzaki H, Yamamoto H, Kenyon CJ, Elmquist JK, Morton NM, Paterson JM, et al. Transgenic amplification of glucocorticoid action in adipose tissue causes high blood pressure in mice. J Clin Invest 2003;112:83-90.

9. Morton NM, Paterson JM, Masuzaki H, Holmes MC, Staels B, Fievet $\mathrm{C}$, et al. Novel adipose tissue-mediated resistance to diet-induced visceral obesity in 11ß-hydroxysteroid dehydrogenase type 1 deficient mice. Diabetes 2004;53:931-8.

10. Cushing $\mathrm{H}$. The basophil adenomas of the pituitary body and their clinical manifestations (pituitary basophilism). Bull Johns Hopkins Hosp 1932;50:137-95.

11. Stewart PM. Tissue-specific Cushing's syndrome, 11ß-hydroxysteroid dehydrogenase and the redefinition of corticosteroid hormone action. Eur J Endocrinol 2003;149:163-8.

12. Stewart PM. The adrenal cortex. In: Larsen PR, Kronenberg HM, Melmed S, Polonsky KS, Foster DW, Wilson JD. Williams textbook of endocrinology. $10^{\text {th }}$ ed. Philadelphia: Saunders, 2003. pp. 491-539.

13. Lönn L, Kvist H, Ernest I, Sjöström L. Changes in body composition and adipose tissue distribution after treatment of women with Cushing's syndrome. Metabolism 1994;43: 1517-22.

14. Rebuffe-Scrive M, Krotkiewski M, Elfverson J, Bjorntorp P. Muscle and adipose tissue morphology and metabolism in Cushing's syndrome. J Clin Endocrinol Metab 1988;67: 1122-8.

15. Walker BR. Extra-adrenal regeneration of glucorticoids by 11ß-hydroxysteroid dehydrogenase type 1: physiological regulator and pharmacological target for energy petitioning. Proc Nutr Soc 2007;66:1-8.
16. Reaven GM. Role of insulin resistance in human disease. Diabetes 1988;37:1595-607.

17. Ljung $T$, Andersson B, Bengtson BA, Bjorntorp P, Marin P. Inhibition of cortisol secretion by dexamethasone in relation to body fat distribution: a dose response study. Obes Res 1996;4:277-82.

18. Jessop DF, Dallman MF, Flaming D, Lightman SL. Resistance to glucocorticoid feedback in obesity. J Clin Endocrinol Metab 2001;86:4109-14.

19. Pasquali R, Ambrosi B, Armanini D, Cavagnine F, Uberti ED, Del Rio G, et al. Cortisol and ACTH response to oral dexamethasone in obesity and effects of sex, body fat distribution, and dexamethasone concentrations: a dose-response study. J Clin Endocrinol Metab 2002;87:166-75.

20. Ljung T, Holm G, Friberg P, Bjorn A, Bengtsson B-A, Svensson J, et al. The activity of the hypothalamic-pituitary-adrenal-axis and the sympathetic nervous system in relation to waist-hip circumference in men. Obes Res 2000;8:487-95.

21. Pasquali R, Cantobelli S, Casimirri F, Capelli M, Bortoluzzi L, Flamia $R$, et al. The hypothalamic pituitary adrenal axis in obese women with different patterns of body fat distribution. J Clin Endocrinol Metab 1993;77:341-6.

22. Purnell JO, Brandon DD, Isabelle LM, Loriaux DL, Samuels $\mathrm{MH}$. Association of $24 \mathrm{~h}$-cortisol production rates, cortisol binding globulin, and plasma free cortisol levels with body composition, leptin levels, and aging in adult men women. $\mathbf{J}$ Clin Endocrinol Metab 2004;89:281-7.

23. Rask $E$, Olsson $T$, Soderberg $S$, Andrew R, Livingstone $D E$, Johnson $\mathrm{O}$, et al. Tissue-specific dysregulation of cortisol metabolism in human obesity. J Clin Endocrinol Metab 2001:86:1418-21.

24. Masuzaki H, Paterson JM, Shinyama H, Morton NM, Mullins JJ, Seckl JR, et al. A transgenic model of visceral obesity and the metabolic syndrome. Science 2001;294:2166-70.

25. Paterson JM, Morton NM, Fievet C, Kenyon CJ, Holmes MC, Staels B, et al. Metabolic syndrome without obesity: hepatic

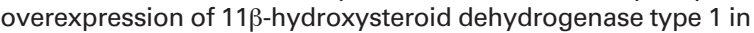
transgenic mice. Proc Nat Acad Sci USA 2004; 101:7088-93.

26. Morton NM, Ramage L, Seckl JR. Down-regulation of adipose tissue $11 \beta$-hydroxysteroid dehydrogenase type 1 by high fat feeding in mice: a potential adaptive mechanism counteracting metabolic disease. Endocrinology 2004;145:2707-12.

27. Alberts $P$, Engblom L, Eddling N, Forsgren M, Klingstron G, Larsson C, et al. Selective inhibition of $11 \beta$-hydroxysteroid dehydrogenase type 1 decreased blood glucose concentrations in hyperglycaemic mice. Diabetologia 2002;45:1528-32.

28. Hermanowski-Vosatka A, Blakovec JM, Cheng K, Chen HY, Hernandez, Koo GC, et al. 11ß-HSD1 inhibition ameliorates metabolic syndrome and prevents progression of atherosclerosis in mice. J Exp Med 2005;202:517-27.

29. Paulmyer-Lacroix O, Boullu S, Oliver C, Alessi MC, Grino M. Expression of the mRNA coding for 11ß-hydroxysteroid dehydrogenase type 1 in adipose tissue from obese patients: an in situ hybridization study. J Clin Endocrinol Metab 2001;87:2701-5.

30. Wake DJ, Rask E, Livingstone, Sodeberg S, Olsson T, Walker $B R$. Local and systemic impact of transcriptional up-regulation of $11 \beta$-hydroxysteroid dehydrogenase type 1 in adipose tissue in human obesity. J Clin Endocrinol Metab 2003;88:3983-8.

31. Lindsay RS, Wake JW, Saraswathy N, Bunt J, Livingstone DEW, Permana PA, et al. Subcutaneous adipose 11 $\beta$-hydroxysteroid dehydrogenase type 1 activity and messenger ribonucleic acid levels are associated with adiposity and insulinemia in Pima Indians and Caucasians. J Clin Endocrinol Metab 2003;88:2738-44.

32. Engeli S, Bohnke J, Feldpausch M, Gorzelniak K, Heintze U, Janke $\mathrm{J}$, et al. Regulation of $11 \beta-$ HSD genes in human adipose tissue: influence of central obesity and weight loss. Obes Res 2004;12:9-17.

33. Tomlinson JW, Sinha B, Bujalska I, Hewison M, Stewart PM. Expression of $11 \beta$-hydroxysteroid dehydrogenase type 1 in adipose tissue is not increased in human obesity. J Clin Endocrinol Metab 2002;87:5630-5. 
34. Sandeep TC, Andrew R, Homer NZM, Andrews RC, Smith K, Walker BR. Increased in vivo generation of cortisol in adipose tissue in human obesity and the effects of the $11 \beta$-hydroxysteroid dehydrogenase type 1 inhibitor carbenoxolone. Diabetes $2005 ; 54: 872-9$.

35. Tomlinson JW, Moore J, Cooper MS, Bujalska I, Shahmanesh M, Burt C, et al. Regulation of the expression of 11/-hydroxysteroid dehydrogenase type 1 in adipose tissue-specific induction by cytokines. Endocrinology 2001;142:1982-9.

36. Andrew R, Philips DIW, Walker BR. Obesity and gender influence cortisol secretion and metabolism in man. J Clin Endocrinol Metab 1998;83:1806-9.

37. Stewart PM, Boulton A, Kumar S, Clark PMS, Shackleton CHL. Cortisol metabolism in human obesity: impaired cortisonecortisol conversion in subjects with central adiposity. J Clin Endocrinol Metab 1999;84:1022-7.

38. Franks PW, Knowler WC, Nair S, Koska J, Lee Y-H, Lindsay RS, et al. Interaction between an 11 $\beta$-HSD1 gene variant and birth era modifies the risk of hypertension in Pima Indians. Hypertension 2004;44:681-8.

39. Nair S, Lee YH, Lindsay RS, Walker BR, Tataranni PA, Bogardus $C$, et al. $11 \beta$-hydroxysteroid dehydrogenase type 1 : Genetic polymorphisms are associated with type 2 diabetes in Pima Indians independently of obesity and expression in adipocyte and muscle. Diabetologia 2004;47:1088-95.

40. Draper N, Echwald SM, Lavery GG, Walker EA, Fraser R, Davies $E$, et al. Association studies between microsatellite markers within the gene encoding for human $11 \beta$-hydroxysteroid dehydrogenase type 1 and body mass index, waist to hip ratio, and glucocorticoid metabolism. J Clin Endocrinol Metab 2002:87:4984-90.

41. Mariniello B, Ronconi V, Rilli S, Bernante P, Boscoro M, Mantero $F$, et al. Adipose tissue $11 \beta$-hydroxysteroid dehydrogenase type 1 expression in obesity and Cushing's syndrome. Eur J Endocrinol 2006;155:435-41.

42. Espíndola-Antunes D, Goto EM, Guimarães AO, Pesquero JB, Silva-Júnior JA, Kater CE. Quantitative mRNA expression of 11/-hydroxysteroid dehydrogenase type 1 and glucocorticoid receptor alpha in visceral adipose tissue of patients with Cushing's syndrome and obese and non-obese controls. Proc Endocr Soc Meeting 2007; [abstract].

43. Tomlinson JW, Moore JS, Clarck PMS, Holder G, Shakespeare L, Stewart PM. Weight loss increases 11ß-hydroxysteroid dehydrogenase type 1 expression in human adipose tissue. J Clin Endocrinol Metab 2004;289:2711-6.
44. Tomlinson JW, Walker EA, Bujalska IJ, Draper N, Lavery GG, Cooper MS, et al. 11ß-hydroxysteroid dehydrogenase type 1: a tissue specific regulator of glucocorticoid response. Endocr Rev 2004;25:831-66.

45. Wake DJ, Stimson RH, Tam GD, Homer NZM, Andrew R, Carpe $F$, et al. Effects of peroxisome proliferator-activated receptor $\alpha$ and $\gamma$ agonists in 11 $\beta$-hydroxysteroid dehydrogenase type 1 in subcutaneous adipose tissue in men. $\mathbf{J}$ Clin Endocrinol Metab 2007;92:1848-56.

46. Basu R, Singh R, Basu A, Johson CM, Rizza RA. Effect of nutrient ingestion on total-body and splanic cortisol production in humans. Diabetes 2006:55:667-74.

47. Wake DJ, Homer NZD, Andrew R, Walker BR. Acute in vivo regulation of $11 \beta$-hydroxysteroid dehydrogenase type 1 by insulin and intralipid infusions in humans. J Clin Endocrinol Metab 2006;91:4682-8.

48. Harris HJ, Kotelevtsev Y, Mullings JJ, Seckl JR, Holmes MC. Intracellular regeneration of glucocorticoids by $11 \beta$-hydroxysteroid dehydrogenase (11ß-HSD)-1 plays a key role in regulation of the hypothalamic-pituitary-adrenal axis: analysis of 11ß-HSD-1-deficient mice. Endocrinology 2001;142:114-20.

49. Stulnig TM, Waldhausl W. 11/-hydroxysteroid dehydrogenase type 1 in obesity and type 2 diabetes. Diabetologia 2004; 47:1-11.

50. Walker BR, Connacher AA, Lindsay RM, Webb DJ, Edwards CRW. Carbenoxolone increases hepatic insulin sensitivity in man: a novel role for 11-oxosteroid reductase in enhancing glucocorticoid receptor activation. J Clin Endocrinol Metab 1995;80:3155-9.

51. Andrews RC, Rooyackers O, Walker BR. Effects of the $11 \beta$ hydroxysteroid dehydrogenase inhibitor carbenoxolone on insulin sensitivity in men with type 2 diabetes. J Clin Endocrinol Metab 2003;88:285-91.

Address for correspondence:

Claudio E. Kater

Laboratório de Esteróides

Disciplina de Endocrinologia - UNIFESP

Rua Pedro de Toledo 781, $13^{\circ}$ andar

04062-023 São Paulo, SP

E-mail: kater@unifesp.br 